\title{
МИСТЕЦТВОЗНАВСТВО
}

DOI: https://doi.org/10.32839/2304-5809/2020-10-86-19

УДК 7.091

Демченко С.-А.Я., Лань О.Б., Луньо П.Є.

Львівський національний університет імені Івана Франка

\author{
ВІЗУАЛІЗАЦІЯ ХУДОЖНЬО-ПЛАСТИЧНОГО ОБРАЗУ \\ В КОНТЕКСТІ КОЛЬОРУ ЕНЕРГЕТИКИ ЧАКР ЛЮДИНИ
}

\begin{abstract}
Анотація. У статті з'ясована проблема перерозподілу енергетики в організмі людини, в їі ефрірному тілі. Проаналізовано зв'язок між енергетикою людини, її поведінкою і залежністю від надлишку або недостачі енергії в певній чакрі. Вияснено, як поведінка людини відображена у хореографрічному образі. Здійснено створення пластично-художнього образу на прикладі енергетики та кольору чакр людини. Встановлено особливості створення динаміки образу, його характеру та поведінку індивіда. Проаналізовано та виокремлено особливість асанів та їх зв'язок з самопочуттям та вираженням власного я. Поставлено питання дослідження невирішених раніше частин загальної проблеми: особистісних проявів креативної творчості хореографа, пов'язаних із художньо-образними асощіаціями щодо кольору енергетичних чакр людини та створення творчого продукту із використанням в хореографічній лексиці відповідних асан йоги. Наведено приклади використання авторами-хореографами особливого спектру кольорів як вихідних джереласоціацій в процесі створення сценарію хореографічних вистав; визначено ракурси дослідження творчості балетмейстера, його креативності та самореалізації.
\end{abstract}

Ключові слова: особистість, мистецтво, чакри, хореографічний образ, колір, енергетика, біополе, енергетичні канали, асани.

Demchenko Yeva-Anna, Lan Oksana, Luno Petro Ivan Franko National University of Lviv

\section{VISUALIZATION OF THE ART-PLASTIC IMAGE IN THE CONTEXT OF THE COLOR OF ENERGY OF THE CHAKR OF THE HUMAN}

Summary. The article clarifies the problem of redistribution of energy in the human body, in its etheric body. Seven main energy channels (chakras) are described, which are located on the line of the human rod, their location, spectrum, color, sound, anatomical and physical image. The characteristics of each chakra are given, where the color of the chakra is indicated, which indicates certain fluctuations of energy in the human body with different frequency and amplitude and the correspondence of each of the chakras to a special lotus flower with different number of petals. There is a regularity of lack of energy in a chakra, and this is reflected in the physical body. Psychosomatics has also been linked to illness and emotional state. The personal manifestations of the choreographer's creative creativity, connected with artistic and figurative associations with the color of human energy chakras and the creation of a creative product using the appropriate yoga asanas in the choreographic vocabulary, were studied. The relationship between human energy, behavior and dependence on excess or lack of energy in a particular chakra is analyzed. Find out how human behavior is reflected in a choreographic image. The creation of a plastic-artistic image on the example of energy and color of human chakras is carried out. The peculiarities of creating the dynamics of the image, its character and behavior of the individual are established. The peculiarity of asanas and their connection with well-being and self-expression are analyzed and singled out. The question of researching previously unsolved parts of the general problem arises: personal manifestations of the choreographer's creative work, associated with artistic associations with the color of human energy chakras and creating a creative product using choreographic vocabulary using appropriate yoga asanas. Examples of choreographers using a special range of colors as sources-associations in the process of creating a script for choreographic performances are given; the prospects of research of creativity of the choreographer, his creativity and self-realization are defined.

Keywords: personality, art, chakras, choreographic image, color, energy, biofield, energy channels, asanas.

Постановка проблеми. Проблема розподі1 лу людської енергетики у ї̈ біополі $є$ постійним джерелом защікавлення багатьох людей як в теоретичній сорері, тобто основні принципи чакр i їх зв'язок із психосоматикою, так і в практичні copepi - йога і необхідні асани для підвищення рівня чакри. Враховуючи популярність цьог напрямку, ця тема розгалужується на багато верств і застосовуеться у хореографічній лексиці за допомогою асанів та художньо-пластичного образу.

Аналіз досліджень та публікацій. На сьогоднішній день дослідженню проблеми перерозподілу енергетики в організмі людини присвяче- но не так багато наукових робіт. Тим не менше певні аспекти цієї проблематики було розглянуто у роботах Анодеа Д. [1], Лой-Со [6, 7], Сан Лайт [10]. Також аналізу та виокремленню особливості асанів та причетності йоги до пластичного образу описано у наукових роботах Громаковская Т. [3], Липень А. [5]. Проблематику креативності і її зв'язок з психологією людини вивчали Баришева Т. [2] та Жигалов Ю. [2].

Виділення невирішених раніше частин загальної проблеми. Дослідження особистісних проявів креативної творчості хореографра, пов'язаних iз художньо-образними асоціаціями 
щодо кольору енергетичних чакр людини та створення творчого продукту із використанням в хореографрічній лексиці відповідних асан йоги.

Мета дослідження. З'ясувати проблему перерозподілу енергетики в організмі людини, проаналізувати зв'язок між тілом людини та її енергетичною сферою, її поведінку у зв'язку 3 надлишком чи недостачею енергії в тій чи іншій чакрі. Розглянути асани для покращення стану чакр людини як джерело можливості створення художньо-пластичного образу в особливій хореографічній лексиці.

Виклад основного матеріалу. Чакри - це енергетичний центр людини, і кожна 3 них відповідае своєму органу, кольору та формуе людське біополе. Кольори їні вказують на певні вібрації енергії і кожна 3 них вібруе 3 певною частотою і амплітудою [7, с. 2-4]. Вважається, що чакри відкрилися людству після довгої практики йогів. В процесі вони побачили людське біополе та описали чакри як квітки лотоса [14].

Для людини дуже важливо знати та розуміти, які процеси з огляду на енергію відбуваються в тілі. Адже все взаємопов'язано. Коли тіло несе в собі нестачу енергії, тої чи іншої чакри, це відображається у фізичному плані. Стан здоров'я, пристрасті, погані звички, позитивні та негативні риси. Також знання про будову біополя дае змогу вияснити, що відбувається з тілом $\mathrm{i}$, якщо це потрібно, зрозуміти, як відкоригувати негативні риси. За допомогою цьго накопичити більше енергії і зберегти їі. Це дає змогу скерувати енергію в потрібне русло. Кожен у процесі свого розвитку має не лише очистити свої енергетичні канали (наді), а й збільшити кількість та покращити якість енергії. Практик повинен бути готовий до того, що коли процес самовдосконалення буде відбуватися, стануть явними не тільки позитивні якості, а й усі негативні, котрі до того були у сплячому режимі. Чакри, котрі розташовані у нижні частині тіла працюють на низьких частотах, відповідно ті, що зверху, працюють на високих частотах і $є$ відповідальними за неземні стани. Варто зазначити, що е три енергетичних канали - наді, місячний та сонячний, ці канали, як по спіралі, проходять в чакри [12].

Основних енергетичних каналів (чакр), котрі йдуть по стержневій лінії людини ссім. Коженз них має свою локалізащію, колір, спектр, звук і анатомо-фрізіологічне представництво [10, с. 8-13]. Перша чакра, коренева - Муладхара. Володіє червоним кольором з символом квітки лотоса 3 чотирма листками і розташована в основі хребта. Муладхара в гармонії несе в собі активність, силу і витримку, а коли вона у дисбалансі - переживання та бажання вижити. Друга чакра - Свадхістхана, сакральна, розташована в районі куприку, колір їі помаранчевий з символом лотоса 3 шести листків. Гармонійність чакра представляє через сексуальність та задоволення, а дисбаланс проявляється у ревності, агресії та самотності. Третьою, в сонячному сплетінні розташована чакра - Маніпура, жовта 3 квіткою лотоса, котрий складається 3 десяти листків. Коли чакра в балансі вона являє собою інтелект, впевненість та оптимізм, 3 негативного боку це високо мірність та постійна напруга. Серцева чакра - Анахата, є четвертою по порядку, зелена, її символом є лотос з дванадцятьма листками. Чутлива у гармонії проявляеться разом з щирістю та співчутливістю, дисгармонія ж показуе нам невпевненість у собі та діях світу. Горлова, чакра - Вішудха, блакитний лотос з шістнадцятьма листками. Ії прояв у збалансованому стані - спілкування та турбота, натомість дисбаланс поєднує у собі стан закритості та постійної брехні. В центрі лоба розташована чакра - Аджна, називається також - Третім оком, представлена синім лотосом 3 двома листками. Володіє баченням реальних речей та відповідальністю, дисгармонія у чакрі несе за собою недовіру. Остання чакра коронна на потилиці називається - Сахасрара. Символом чакри є фріолетовий лотос з тисячею листків. Усвідомлення усього та мудрість - ознаки гармонії, а в дисгармонії несе за собою мінуси усіх чакр [1, с. 5-7].

Будь-яка зміна кольору, фрорми чи положення чакри означає дисфункцію органів людини, за котрі відповідае чакра.

Колір відіграє важливу роль у стані чакр. Він активуе роботу певних енергетичних центрів, а саме: абстрактне мислення, споглядання, співчуття, ідеалізація і дія. Також, враховуючи індивідуальні психосоматичні особливості глядачів, можна сказати, що сприйняття одніеї картини в кожної людини буде різне [13].

Аби відновити баланс чакр варто прислухатися до власного тіла і розуміти, яку чакру треба стимулювати. Якщо тіло стомлене треба виконувати позу, котрі працюють з пупковою чакрою, аби знову розпалити вогонь у тілі, у випадку відчуття тривоги варто виконувати позу, котрі стимулюють земні чакри. Наступними вправами можна покращити самопочуття і ввести гармонію у певних чакрах [6, с. 26]. Муладхара - у цій чакрі усі наші спогади, якщо ця чакра заблокована, самооцінка різко падає і людина почувається нещасливою. Врікшасана - вправа, котра стабілізуе впевненість у собі, безпеку. Ноги на ширині плечей, права нога притиснута до верхньої частини лівого бедра, куприк опущений вниз, хребет витягуеться догори [3, с. 8]. Свадхістхана - репродуктивна чакра, коли вона у дисбалансі людина відчуває емоційну нестійкість, почуття провини. Девіасана - вправа спрямована на отримання творчої енергії. Ноги широко розставлені, бедра опущені вниз, таким чином вони на одному рівні з колінами. Руки лежать на бедрах, куприк опущений вниз. Маніпура у дисгармонії не надає людині рішучості, низька самооцінка та інертний стан. Навасана - сидячи на підлозі ноги підняті під кутом 60 градусів, руки витягнуті вперед рівні, спина також рівна. За допомогою цієї вправи прокидається внутрішня енергія [3, с. 26]. Анахата - скупчення енергії безумовного кохання. Заблокована чакра веде за собою в людини егоїстичну поведінку, в результаті самотність та відречення. Уштрасана - стоячи на колінах, таз піднятий догори, прогнутися назад. Беручись за п'ятки прогнутися назад. Стимуляція ціеї чакри лікуе рани і заново відкриває серце та душу [3, с. 32]. Вішудха - чакра, без балансу котрої, людина не може отримати свій власний голос та свою правду. Вправа Саламба Сарвангасана допоможе відкрити чакру, де голос пересікає простір і людина виражає свої емоції правильно. Лежачи на спині, підняти 
ноги на дев'яносто градусів. За допомогою рук, підняти ноги догори під рівним кутом, лежачи на лопатках [3, с. 38]. Аджна - чарка, котра відповідає за інтуїцію, а також відповідає за роботу інших чакр. Сукхасана - вправа, котра допоможе людині побачити повну картину світу. Сидячи у позі лотоса (ноги схрещені), з рівною спиною, хребет тягнеться догори. Руки можна покласти збоку або на коліна [3, с. 19]. Сахасрара - чакра пов'язана 3 духовним початком і коли вона закрита приносить людині страждання [5, с. 12]. Шавасана - вправа, за допомогою котрої тіло може відчути звільнення 3 будь-якої ситуації. Лежачи на спині, повністю розслабитися, для кращого ефректу закрити очі. Щоб почути фрізичне тіло, зберігаючи зв'язок з вічним «я» [11].

Провівши ланцюг Чакра - «колір чакри» ключове слово відповідності чакри в тілі - ситуація - поведінка - характер - образ, можна побачити взаємопроникність його елементів як похідних, що витікають одна із другої.

Трансформація, в даному випадку, «характеру кольору» в його пластичне вираження відбувається лише за його (автора) особистими відчуттям та арсеналом рухів.

Логічна послідовність колір - танець - костюл не є новизною. Колір як структура приваблював таких хореографів як Іржі Кіліяна, Мерса Каннінгема та ін.

Візуалізація художніх образів у балетмейстера 3 розвинутою уявою відбувається практично відразу при постановці завдання. Конструктивне та абстрактне мислення, здатність до процесів композиції (композиторства - авт.) надають автору хореографру широкі можливості для самовираження. Прикладом використання кольору як асоціації хореографічного образу також можуть бути дипломні вистави студентівхореографрів кафедри режисури i хореографріï факультету культури і мистецтв Львівського національного університету імені Івана Франка: «Танець чорнил» - одноактний балет-перформанс за авторським лібрето (А. Іващишин, спеціаліст, 2014 р.), «Зцілення мистецтвом» - хореографічна вистава-портрет за мотивами біографрї Фріди Кало (Л. Хухра, магістр, 2019 р.), «Секондхенд «Кохання» - танцювальна вистава в стилі джаз-танщю за авторським лібрето (К. Мосесова, магістр, 2019 р.). Спектр вибраних авторами-хореографами кольорів був пов'язаний із певними асоціаціями в житті людини: настроєм, долею, відносинами тощо. Колір був чіткою асоціацією до характеру та дії персонажів, цих створених хореографрічних образів.

В своїх дослідженнях автор (О. Лань) не вперше торкається теми створення художнього хореографрічного образу: в статті «Художне кредо балетмейстера як наслідок його світогляду в контексті створення хореографрічного образу» зазначається важливість свободи самовиражен- ня молодого хореографра, його високого інтелектуального розвитку в соціумі та відображення особистого світосприйняття у створених ним хореографрічних образах. Зазначається, що «художнє кредо як спосіб саморозвитку творчої особистості стало невід'ємною частиною нашого часу» [4, с. $137-144]$.

В контексті зазначеного слід сказати, що творчість балетмейстера, його становлення та реалізація е темою широкого дослідження. Установку на самореалізацію особистості як вектор здатності до творчості розглядав А. Маслоу. Головну роль в детермінації творчої поведінки він віддавав мотивації, цінностям та особистісним рисам [8, с. 304].

Важливою складовою творчості балетмейстера можна назвати його креативність, яку Баришева Т.А. та Жигалов Ю.А. визначають як багаторівневе системне психічне утворення, що включає в собі емоції, мотивацію, інтелектуальний потенціал, естетичний розвиток, компетентність та комунікабельність [2, с. 268].

В цьому контексті ще одну грань балетмейстерської діяльності ми бачимо у дослідженні Л.К. Пацунової: «...минуло понад пів століття, протягом якого мистецтво мізансцени пройшло величезний шлях від виявлення дї, логіки, зіткнень $i$ конфбіктів до творення художніх тропів: метафбор, силволів, алегорій, гіпербол тощо, що слугують виявленню сутності характерів, подій та явищ, а також підносять сценічний твір до рівня високої фрілософрської образності. Під могутнім впливом театру мистецтво балетмейстера пройшло великий шлях у напрямку мистецтва образно-пластичної режисури» [9, с. 212].

Висновки та пропозиції. Вивчаючи тему «чакр» та «біополя» людини ми розуміємо, що чакри - це скупчення певної енергії у певній частині тіла. Кожна 3 них характеризуеться власним кольором, лотосом, власним розположенням та відповідає за ту чи іншу емоцію, фрункцію нашої поведінки. Зв'язок людини з їі енергетичною сорерою більший ніж ми собі можемо уявити, адже, як і в психосоматиці, кожна наша дія, хвороба тісно пов'язана 3 нашими проблемами в голові. Надлишок цієї енергії чи її недостача може привести до дисбалансу чакри, відповідно і проблем, котрі вона за собою несе. Порівнюючи йогу, асани з хореографією можна сказати, що багато елементів танцюрист використовує на щодень. Аналізуючи асани в йозі розуміємо, що вони покращують не лише наше самопочуття, а й допомагають у розтяжці м'язів ніг чи живота. Щодо самої хореограdiï - поєднуючи асани та танщювальну лексику ми будуємо танець, а за допомогою характеру кольору тієї чи іншої чакри передаємо почуття, переживання в образі танцівника. Це надає додаткові можливості розширенню креативного простору автора-хореографа та спонукає до вивчення взаємозв'язків між духовним та матеріальним в нашому проявленому світі.

\section{Список літератури:}

1. Анодеа Д. Чакры. Полная энциклопедия. Москва, 2017. 304 с.

2. Барышева Т.А., Жигалов Ю.А. Психолого-педагогические основы развития креативности : Учебное пособие. Санкт-Петербург, 2006. 268 с.

3. Громаковская Т. Йога-анатомия. Как работают асаны для здоровья и стройности тела. Москва, 2012.264 с.

4. Лань О. Художне кредо балетмейстера як наслідок його світогляду в контексті створення хореографрічного образу. Вісник ЛНУ іли. Івана Франка. 2014. № 14. С. 137-144. 
5. Липень А. Простая йога. Лучшие асаны. Санкт-Петербург, 2010. 42 с.

6. Лой-Со. Йога с нуля. Основные асаны. Санкт-Петербург, 2010. 29 с.

7. Лой-Со. Чакры - источники внутренней силы. Санкт-Петербург, 2010. $24 \mathrm{c.}$

8. Маслоу А. Психология бытия. Киев, 1997. 304 с.

9. Пацунова Л. Образно-пластична режисура як вершина мистецтва балетмейстера. Молодий вчений. 2017. № 9(49). С. 212.

10. Сан Лайт. Чакры - энергии жизненных сфер. Работа с внутренним космосом. Москва, 2012. 32 с.

11. 7 асан для 7 чакр. URL: https://yogajournal.ru/body/practice/forbeginners/7-asan-dl-7-chakr/ (дата звернення: 05.04.2020).

12. Васильев О. Чакры: строение, фрункции, свойства. Их влияние на нашу жизнь. 7 чакр. URL: https://www.oum.ru/ yoga/osnovy-yogi/chakri-ih-vliyanie-na-gizn/ (дата звернення: 05.04.2020).

13. О некоторых взаимосвязях цвета и состояния человека. URL: http://roerich.spb.ru/article/o_nekotoryh_ vzaimosvyazyah_cveta_i_sostoyaniya_cheloveka (дата звернення: 05.04.2020).

14. Стрельцова С. Цвета чакр человека: что означают. URL: https://108lepestkov.com/energetika/chakry-potsvetam-i-nazvaniyam.html (дата звернення: 05.04.2020).

\section{References:}

1. Anodeya, D. (2017). Chakry. Polnaya entsiklopediya [Chakras. Complete encyclopedia]. Moscow: Eksimo. (in Russian)

2. Barysheva, T., \& Zhigalov, Yu. (2006). Psikhologo-pedagogicheskiye osnovy razvitiya kreativnosti [Psychological and pedagogical foundations for the development of creativity]. St. Petersburg. (in Russian)

3. Gromakovskaya, T. (2012). Yoga-anatomiya. Kak rabotayut asany dlya zdorov'ya $i$ stroynosti tela [Yoga Anatomy. How asanas work for health and slimness of the body]. Moscow: Litres. (in Russian)

4. Lan', O. (2014). Khudozhnye kredo baletmeystera yak naslidok yoho svitohlyadu v konteksti stvorennya khoreohrafichnoho obrazu [The artistic credo of the choreographer as a consequence of his worldview in the context of creating a choreographic image]. Visnyk LNU im. Ivana Franka, vol. 14, pp. 137-144.

5. Lipen', A. (2010). Prostaya yoga. Luchshiye asany [Simple yoga. The best asanas]. St. Petersburg: Piter. (in Russian)

6. Loy-So (2010). Yoga s nulya. Osnovnyye asany [Yoga from scratch. Basic asanas]. St. Petersburg: Vektor. (in Russian)

7. Loy-So (2010). Chakry - istochniki vnutrenney sily [Chakras are sources of inner strength]. St. Petersburg: Vektor. (in Russian)

8. Maslou, A. (1997). Psikhologiya bytiya [The psychology of being]. Kyiv: Vakler. (in Ukrainian)

9. Patsunova, L. (2017). Obrazno-plastychna rezhysura yak vershyna mystetstva baletmeystera [Image-plastic directing as the pinnacle of the choreographer's art]. Molodyy vchenyy, no. 9(49), p. 212.

10. San Layt (2012). Chakry - energii zhiznennykh sfer. Rabota s vnutrennim kosmosom [Chakras - energies of living spheres. Working with the inner space]. Moscow: Litres. (in Russian)

11. 7 asan dlya 7 chakr. URL: https://yogajournal.ru/body/practice/forbeginners/7-asan-dl-7-chakr/ (accessed 05.04.2020).

12. Vasil'yev, O. Chakry: stroyeniye, funktsii, svoystva. Ikh vliyaniye na nashu zhizn'. 7 chakr. URL: https://www.oum.ru/ yoga/osnovy-yogi/chakri-ih-vliyanie-na-gizn/ (accessed 05.04.2020).

13. O nekotorykh vzaimosvyazyakh tsveta i sostoyaniya cheloveka. URL: http://roerich.spb.ru/article/o_nekotoryh_ vzaimosvyazyah_cveta_i_sostoyaniya_cheloveka (accessed 05.04.2020).

14. Strel'tsova S. Tsveta chakr cheloveka: chto oznachayut. URL: https://108lepestkov.com/energetika/chakry-potsvetam-i-nazvaniyam.html (accessed 05.04.2020). 